\title{
Selection and validation of optimal endogenous reference genes for analysis of quantitative PCR in four tissues pathologically associated with Kidney-yang deficiency syndrome following influenza $A$ infection
}

\author{
YEPEI FU $^{1 *}$, JIA YANG ${ }^{1 *}$, SHANSHAN FAN ${ }^{1}$, SHAOZHE ZHAO ${ }^{1}$, RUIKUN DU $^{1}$, \\ SYED MUHAMMAD ALI SHAH ${ }^{2}$, MUHAMMAD AKRAM ${ }^{2}$, RONG RONG $^{1,3}$ and YONG YANG YH $^{3,4}$ \\ ${ }^{1}$ College of Pharmaceutical Science, Shandong University of Traditional Chinese Medicine, Jinan, \\ Shandong 250355, P.R. China; ${ }^{2}$ Department of Eastern Medicine, Directorate of Medical Sciences, \\ Government College University of Faisalabad, Faisalabad, Punjab 38000, Pakistan; \\ ${ }^{3}$ Shandong Provincial Collaborative Innovation Center for Antiviral Traditional Chinese Medicine; \\ ${ }^{4}$ Experimental Center, Shandong University of Traditional Chinese Medicine, Jinan, Shandong 250355, P.R. China
}

Received September 15, 2019; Accepted July 22, 2020

DOI: $10.3892 / \mathrm{etm} .2020 .9374$

\begin{abstract}
Kidney-yang deficiency syndrome (KYDS) infected with the influenza virus is a suitable model to imitate a population at high-risk to influenza infection with a high rate of morbidity and mortality. However, the specific molecular mechanisms underlying this disease remain unclear. A stable reference gene is essential as an internal control for molecular biology research of this condition. Reverse-transcription-quantitative PCR (RT-qPCR) is considered an extremely sensitive technique used for absolute and relative quantification of target genes transcript levels. To accurately estimate the relative expression of genes in cells from mice with KYDS in response to infection with influenza A virus subtype H1N1 (A/H1N1) virus using RT-qPCR, it is necessary to identify suitable reference genes. In the present study, analysis of 10 reference genes (Act- $\beta, \beta 2 \mathrm{~m}, \mathrm{GAPDH}$, Gus $\beta$, Tub $\alpha$, Grcc10, Eif4h, Rnf187, Nedd8 and Ywhae) was performed across a set of 4 tissue types: Lung; heart; liver; and kidney. KYDS mice were inoculated with $\mathrm{A} / \mathrm{H} 1 \mathrm{~N} 1$ virus or a
\end{abstract}

Correspondence to: Dr Yong Yang, Experimental Center, Shandong University of Traditional Chinese Medicine, 4655 Daxue Road, Jinan, Shandong 250355, P.R. China

E-mail: yy7204@163.com

${ }^{*}$ Contributed equally

Abbreviations: qPCR, quantitative PCR; KYDS, Kidney-Yang deficiency syndrome; Cq, quantification cycle; geoMean, geometric mean; TLR, toll-like receptor; RIG-I, retinoic acid inducible gene-I

Key words: reference genes, reverse transcription-quantitative PCR, Kidney-yang deficiency syndrome, influenza A virus, influenza A virus subtype $\mathrm{H} 1 \mathrm{~N} 1$ mock control. For analysis, geNorm, BestKeeper, NormFinder, and Bio-Rad Maestro ${ }^{\mathrm{TM}}$ statistical programs were used for the estimation of the stability of the reference genes. The results were authenticated through extended experimental settings using a group of 10 samples, parallel to 3 additional innate immune system-associated genes of the host, TLR3, TLR7 and RIG-I, which were also analyzed using the same algorithms. From the 4 algorithms, taking into account the joint analyses of the ranking order outputs, the 2 genes Ywhae and Nedd8 were identified to be the most stable for mice with KYDS following infection with $\mathrm{A} / \mathrm{H} 1 \mathrm{~N} 1$ virus. In contrast, the least stable genes in all 4 tissues were GAPDH and $\beta 2 \mathrm{~m}$. These results may affect the choice of reference genes in future studies that use RT-qPCR analysis of target genes in experimental conditions, such as mice with KYDS infected with influenza A virus.

\section{Introduction}

At present, reverse transcription-quantitative PCR (RT-qPCR) is an extremely sensitive method for studying absolute or relative gene expression. In absolute quantification of a particular transcript, the input copy number is calculated, whereas for relative quantification, the expression of a reference gene is measured and compared against the expression level of the target gene. Setting up and using a standard curve for relative expression can allow you to accurately estimate absolute quantification from relative quantification (1). qPCR data of target genes can be achieved by relative quantification when internal control genes are used as a reference (2). Absolute quantification is not extensively used by most researchers, whereas relative quantification is frequently used in numerous studies for analysis of gene expression (3). Without considering the experimental conditions, reference genes are designated as internal controls for which, among different samples, gene expression has to be relatively stable. Standardizing the expression profile and making use of suitable reference genes 
may improve the precision and consistency of qPCR $(4,5)$. However, the expression of the reference genes may vary based on differing experimental settings, sample species, tissues, treatments, developmental stages or genotypes $(6,7)$. Therefore, the use of a precise and consistently expressed reference gene under certain conditions is essential for reliable analysis of qPCR.

Influenza is a contagious viral infection that infects millions of people per year worldwide, and has resulted in $\sim 1$ million mortalities as a result of pandemics in the 2009 swine flu (8). Influenza virus results in a severe respiratory tract infection, and has a high rate of morbidity and mortality, particularly in high-risk populations, such as elderly people $(9,10)$. Kidney-yang deficiency syndrome (KYDS) is one of the classical syndrome patterns in Traditional Chinese Medicine (TCM) and is characterized by tenderness and weakness in the knees and lumbar regions, mental fatigue, difficulty in urinating, enuresis, female sterility, problems in hearing and teeth (11). A study investigating 2,067 elderly Chinese individuals ( $>60$ years) revealed that $45.33 \%$ of these patients suffered from KYDS, suggesting that KYDS is the predominant TCM syndrome in high-risk populations (12). Another epidemiological investigation was conducted on 2,137 healthy elderly individuals (>60 years in age), and the results indicated that the rate of kidney deficiency was $78.80 \%$ (13). These data show that there is an increasing trend for elderly patients with a deteriorating health status to suffer from KYDS (14). Therefore, KYDS is the predominant TCM syndrome in high-risk populations $(13,15)$. It is concerning that these elderly patients who suffer from KYDS are also at an increased risk of contracting seasonal influenza infections.

KYDS and influenza A virus subtype H1N1 (A/H1N1) virus infection causes broad ranging variations in gene expression, which form the molecular basis of the biological effects of KYDS following infection with influenza A virus (16-23). To further understand the mechanisms underlying KYDS following infection with influenza $\mathrm{A}$, with the aim of developing an effective treatment for this disease, the changes in gene transcription during infection need to be determined and understood. Our previous study showed that certain commonly used reference genes (GAPDH or Act $\beta$ ) were actually unstable in the lung tissue of KYDS infection with influenza, compared with normal control mice (24). In addition, evaluation of the stability of reference genes in tissues other than the lungs, such as the hearts, livers, and kidneys, following KYDS and infection is important as they are closely associated with and notably affected by KYDS (25-27).

In the present study, 10 candidate reference genes [ $\beta$-actin (Act $\beta), \beta 2$ microglobulin $(\beta 2 \mathrm{~m}), \mathrm{GAPDH}, \beta$-glucuronidase (Gus $\beta$ ), $\alpha$-tubulin (Tub $\alpha$ ), Gene rich cluster, C10 gene (Grcc10), eukaryotic translation initiation factor $4 \mathrm{H}$ (Eif4h), ring finger protein 187 (Rnf187), neural precursor cell expressed, developmentally down-regulated gene 8 (Nedd8), and tyrosine 3-monooxygenase/tryptophan 5-monooxygenase activation protein, epsilon polypeptide (Ywhae)] that are suitable for use as internal reference genes for normalizing gene expression were selected $(17,20,22,28,29)$. The consistency of expression of these genes in a mouse model of KYDS subsequently infected with $\mathrm{A} / \mathrm{H} 1 \mathrm{~N} 1$ virus, or with a mock control, were assessed in tissue samples from four different organs using 4 statistical algorithms: NormFinder; geNorm; Bio-Rad Maestro; and BestKeeper. The aim of the present study was to determine the most accurate reference gene for the calculation of target gene expression in studies investigating KYDS and viral infection.

\section{Materials and methods}

Animals. The present study was performed in accordance with the protocols provided by the Guide for the Care and Use of Laboratory Animals of the National Institutes of Health. The procedure was approved by the Ethic Committee of Shandong University of Traditional Chinese Medicine (approval no. SDUTCM2018091901). Mice were regularly observed by staff veterinarians (Experimental Center, Shandong University of Traditional Chinese Medicine) in specific pathogen-free conditions, at $21-23^{\circ} \mathrm{C}$, with $60-70 \%$ humidity with a $12 / 12 \mathrm{~h}$ light/dark cycle. Isoflurane was used for anesthesia prior to surgery, and suffering was reduced to a minimum. Male SPF BALB/c mice weighing (18-20 g) were purchased from the Jinan Pengyue Experimental Animal Breeding Co., Ltd. A total of 40 animals were used in the present study. The mice were acclimated for 3 days, and separated into two groups, with 20 animals in each group. The mice were treated for 2 weeks as follows: The model group received serial intraperitoneal inoculation with $8 \mathrm{mg} / \mathrm{kg}$ estradiol benzoate for 7 days for mice in the KYDS group, as described previously $(30,31)$; and the normal control group received intraperitoneal injection with $0.1 \mathrm{ml}$ saline. The rectal temperature and body weight were examined prior and subsequent to infection. The levels of spontaneous locomotor activity of the mice were evaluated in open field tests in an automated mode using a mouse autonomic activity instrument (ZIL-2 locomotor activity automatic measuring instrument; Institute of Materia Medica, Chinese Academy of Medical Sciences), as described previously (32). Animals were placed individually into a chamber with opaque Perspex ${ }^{\circledR}$ walls and floors and a transparent Perspex ${ }^{\circledR}$ lid. The chamber was equipped with infrared photobeams connected to a computer to collect spontaneous locomotor activity. Mice were acclimated to the chambers for $3 \mathrm{~min}$. The spontaneous locomotor activity, defined as the total accumulated counts of a horizontal single photobeam interruption, was collected for a period of $10 \mathrm{~min}$. The swimming time was measured with forced swim test (FST), as described previously (33). FST is often used as a method of measuring the degree of exercise fatigue in rodents. For the FST, mice were placed individually into a plastic cylinder containing water $\left(24 \pm 1^{\circ} \mathrm{C}\right)$. The cylinder water was sufficiently deep to ensure that the animals' hind paws could not touch the bottom of the cylinder. An iron weight, weighing 5\% of mouse body weight, was attached to animals' tail using masking tape. The swimming time was recorded until the mice became exhausted and were rescued within $1 \mathrm{~h}$. A total of 10 animals were selected randomly in each group to measure the serum steroid hormones (estradiol and progesterone) and thyroid hormones (T3 and T4) by xMAP ${ }^{\circledR}$ technology in a flow cytometry-based Luminex 200 instrument with xPONENT software 3.1 for analysis (Luminex Corporation). This kit was Multi-Species 
Hormone Magnetic Bead Panel (cat. no. MSHMAG-21K) and was purchased from EMD Millipore, including Multi-Species Hormone Standard (cat. no. MSPHM-8021), Multi-Species Hormone Quality Controls 1 and 2 (cat. no. MSPHM-6021), Multi-Species Hormone HRP Conjugate (cat. no. MSPHM-HRP), Streptavidin-Phycoerythrin (cat. no. MC-SAPE2). The Multi-Species Hormone Magnetic Bead Panel Assay was performed according to the manufactuer's protocol (http://www.millipore.com), using the following antibody beads and dilutions: Anti-Estradiol Bead (cat. no. ESTRDL-MAG, 40:1), Anti-Progesterone Bead (cat. no.PRGST-MAG; 40:1), Anti-T3 Bead (cat. no. T3-MAG; 40:1) and Anti-T4 Bead (cat. no. T4-MAG; 40:1) and Multi-Species Hormone Detection Antibody (cat. no. MSPHM-1021). These animals were anesthetized with $3.5-4.5 \%$ isoflurane for induction when observed for loss of righting reflex and the breathing pattern had become deeper and slower on the 7 th day post-injection, and $0.5-0.8 \mathrm{ml}$ blood samples were collected via retro-orbital bleeding procedure. The animals were then sacrificed by cervical dislocation following blood collection. On the 8th day, mice in the model group were anaesthetized with 3.5-4.5\% isoflurane for induction (when animals should not respond to noxious stimuli via a toe pinch or loss of righting reflex), and $20 \mu \mathrm{l}$ viral suspension containing a hemagglutination titer of 1:320 of virus influenza A/FM/1/47 (donated by Professor Hong Meng, Shandong Academy of Medical Sciences) was dropped into the nose. The mice in the control group were inoculated with $20 \mu \mathrm{l}$ normal saline. All mice were subsequently given ad libitum access to food and water. Three mice that had lost $25 \%$ of their original weight during the course of infection were sacrificed, and one mouse succumbed during the entire study period. Schematic illustration of the experimental timeline was displayed in Fig. 1.

Tissue preparation. On the 14th day, mice were subjected to anesthesia with $3.5-4.5 \%$ isoflurane, when animals were monitored for loss of righting reflex and the breathing pattern had become deeper and slower, then sacrificed by cervical dislocation. The lung, heart, liver, and kidney tissues were isolated, and weighed for the organ index calculation, using the following formula: Visceral index=weight of organ x100/bodyweight. Following harvesting, small tissue samples were immediately submerged in RNAstore Reagent (Tiangen Biotech Co., Ltd.) at a dilution ratio of 1:10 (w/v), and stored at $4^{\circ} \mathrm{C}$ until use.

Total RNA extraction. RNAprep Pure Tissue kit (Tiangen Biotech Co., Ltd.) was used for total RNA extraction from 10-20 mg tissue samples according to the manufacturer's protocol. Production and purity of RNA was estimated using a Quawell 5,000 spectrophotometer (Quawell Technology, Inc.). Samples with an optical density between 1.9-2.1 when measured with an absorbance ratio of 260/280 were used for subsequent analysis. Subsequently, $1 \%$ agarose gel electrophoresis was used to assess the integrity of RNA with GeneRed nucleic acid dye (Tiangen Biotech Co., Ltd.).

Reverse transcription-quantitative (RT- $q) P C R$. A reverse transcription FastQuant RT kit with gDNase (Tiangen Biotech Co., Ltd.) was used with random hexamer oligonucleotide primers according to the manufacturer's protocol with $2 \mu \mathrm{g}$ total RNA for $3 \mathrm{~min}$ at $42^{\circ} \mathrm{C}$. Reverse transcription was performed using a FastQuant RT enzyme for $15 \mathrm{~min}$ at $42^{\circ} \mathrm{C}$. Samples were subsequently stored at $-20^{\circ} \mathrm{C}$. For qPCR analysis, nuclease-free water was used to dilute the cDNA samples 10 -fold, and the samples were amplified using a Bio-Rad CFX Connect Real-Time system. Samples were prepared using 6 pmol of both forward and reverse primers, $2 \mu \mathrm{l}$ cDNA and $10 \mu 1$ 2x SuperReal PreMix Plus with SYBR-Green I (Tiangen Biotech Co., Ltd.), made to a final volume of $20 \mu \mathrm{l}$. The thermocycling conditions were as follows: Initial denaturation $15 \mathrm{~min}$ at $95^{\circ} \mathrm{C}$; followed by 40 cycles of $95^{\circ} \mathrm{C}$ for $10 \mathrm{sec}$ and $60^{\circ} \mathrm{C}$ for $32 \mathrm{sec}$; then annealing and elongation $65^{\circ} \mathrm{C}$ for $5 \mathrm{sec}$. Following amplification, the dissociation curves of the PCR products were obtained by addition of a thermal denaturing cycle followed by $65-95^{\circ} \mathrm{C}$ with an increment of $0.5^{\circ} \mathrm{C}$. This was important for verification of amplification specificity.

For each primer pair, computation of qPCR efficiencies in the exponential phase was performed using the standard curves (pooled cDNA was diluted 4-fold serially, which contained equivalent numbers of various sample sets). For every serial dilution, the mean quantification cycle $(\mathrm{Cq})$ values were plotted against the logarithm of the cDNA dilution factor, and the equation: $\mathrm{E}=10$ (-1/slope) x100 was used for calculation, where the gradient of the linear regression line was represented by the slope. The standard curve and correlation coefficients $\left(\mathrm{R}^{2}\right)$ for each gene were used for determination of linear dynamic range.

Primers. Based on previous studies, 10 genes frequently used as endogenous controls were selected as the reference genes. The selected genes were: Act $\beta$; Gus $\beta$; GAPDH; $\beta 2 \mathrm{~m}$; Tub $\alpha$; Grcc10; Eif4h; Rnf187; Nedd8; and Ywhae. NCBI BLAST (blast.ncbi.nlm.nih.gov/Blast.cgi) was used for identification of nucleotide sequences to design primers. Primers were purchased from Beijing Liuhe BGI Technology Company. Table I presents the primer characteristics of candidate reference genes. The sequences of the primers used for analysis of an immune response were: Toll-like receptor 3 (TLR3) forward, CAGGATACTTGATCTCGGCCTT; TLR3 reverse, TGGCCGCTGAGTTTTTGTTC; TLR7 forward, CTG GAGTTCAGAGGCAACCATT; TLF7 reverse, GTTATC ACCGGCTCTCCATAGAA; retinoic acid inducible gene-I (RIG-I) forward, GCAGGTTACTGTGGACTTTGTG; RIG-I reverse, TGCCATTCTCCCTTTAGTGTCT; A/H1N1 virus M forward, 5'-CTGAGAAGCAGATACTGGGC-3'; and A/H1N1 virus $\mathrm{M}$ reverse, 5'-CTGCATTGTCTCCGAAGAAAT-3'.

Data analysis. CFX Maestro ${ }^{\mathrm{TM}}$ software 1.0 (Bio-Rad Laboratories, Inc.) automatic calculation was used to perform threshold setting and baseline correction. CFX Maestro software was also used to determine the $\mathrm{Cq}$ values using the means of the single threshold mode.

A total of 3 common statistical programs, geNorm, BestKeeper. and NormFinder, as well as Bio-Rad Maestro ${ }^{\mathrm{TM}}$ software were used to evaluate the stability of the reference genes. A reference gene selector tool in CFX Maestro Software (version 1.1) was used to analyze a run with multiple genes stability. The $2^{-\Delta \Delta C q}$ formula (3) was used to 
Table I. Primers sequences and characteristics.

\begin{tabular}{|c|c|c|c|c|c|c|}
\hline $\begin{array}{l}\text { Gene } \\
\text { symbol }\end{array}$ & Gene name & $\begin{array}{l}\text { Accession } \\
\text { number }\end{array}$ & Primer sequence & $\begin{array}{l}\text { Amplicon } \\
\text { size }\end{array}$ & Efficiency, \% & $\mathrm{R}^{2}$ \\
\hline $\operatorname{Act} \beta$ & $\beta$-actin & NM_007393.5 & $\begin{array}{l}\text { F: CCTTCTTGGGTATGGAATCCTGT } \\
\text { R: CACTGTGTTGGCATAGAGGTCTTTAC }\end{array}$ & 101 & 98.9 & 0.997 \\
\hline$\beta 2 \mathrm{~m}$ & $\beta 2$ microglobulin & NM_009735.3 & $\begin{array}{l}\text { F: CATGGCTCGCTCGGTGAC } \\
\text { R: CAGTTCAGTATGTTCGGCTTCC }\end{array}$ & 135 & 97.3 & 0.994 \\
\hline GAPDH & $\begin{array}{l}\text { Glyceraldehyde- } \\
\text { 3-phosphate } \\
\text { dehydrogenase }\end{array}$ & NM_008084.3 & $\begin{array}{l}\text { F: TGCACCACCAACTGCTTAG } \\
\text { R: GGATGCAGGGATGATGTTC }\end{array}$ & 177 & 98.1 & 0.999 \\
\hline Gus $\beta$ & $\beta$-glucuronidase & NM_010368.1 & $\begin{array}{l}\text { F: CCGACCTCTCGAACAACCG } \\
\text { R: GCTTCCCGTTCATACCACACC }\end{array}$ & 169 & 93 & 0.998 \\
\hline Tub $\alpha$ & $\alpha$-tubulin & NM_011653.2 & $\begin{array}{l}\text { F: TGTCCTGGACAGGATTCGC } \\
\text { R: CTCCATCAGCAGGGAGGTG }\end{array}$ & 115 & 97.2 & 0.997 \\
\hline Grce 10 & $\begin{array}{l}\text { Gene rich cluster, } \\
\text { C10 gene }\end{array}$ & NM_013535.1 & $\begin{array}{l}\text { F: GCGGAGGTGATTCAAGCG } \\
\text { R: TGACCAGGCGGGCAAACT }\end{array}$ & 196 & 94 & 0.993 \\
\hline Eif4h & $\begin{array}{l}\text { Eukaryotic } \\
\text { translation } \\
\text { initiation factor } 4 \mathrm{H}\end{array}$ & NM_033561.2 & $\begin{array}{l}\text { F: CCTTGGCTCGGGATTGTC } \\
\text { R: TCCGCATTGGAGATGGATTA }\end{array}$ & 198 & 92.9 & 0.999 \\
\hline Rnf187 & $\begin{array}{l}\text { Ring finger protein } \\
187\end{array}$ & NM_022423.2 & $\begin{array}{l}\text { F: CTGGCACCACCCTTCATC } \\
\text { R: ACAAGCCCGAGCACATTC }\end{array}$ & 155 & 93.5 & 0.990 \\
\hline Nedd8 & $\begin{array}{l}\text { Neural precursor } \\
\text { cell expressed, } \\
\text { developmentally } \\
\text { down-regulated } \\
\text { gene } 8\end{array}$ & NM_008683.3 & $\begin{array}{l}\text { F: TGGGAAGGAGATTGAGATAG } \\
\text { R: TTGCTTGCCACTGTAGATG }\end{array}$ & 121 & 93 & 0.997 \\
\hline Ywhae & $\begin{array}{l}\text { Tyrosine } \\
\text { 3-monooxygenase/ } \\
\text { tryptophan } \\
\text { 5-monooxygenase } \\
\text { activation protein, } \\
\text { epsilon polypeptide }\end{array}$ & NM_009536.4 & $\begin{array}{l}\text { F: CCCATTCGTTTAGGTCTT } \\
\text { R: TCCACAGCGTCAGGTTAT }\end{array}$ & 193 & 95.3 & 0.993 \\
\hline
\end{tabular}

$\mathrm{R}^{2}$, standard curve correlation coefficient; F, forward; $\mathrm{R}$, reverse.

transform $\mathrm{Cq}$ values into non-normalized relative quantities, where: $\Delta \mathrm{Cq}=$ corresponding $\mathrm{Cq}$ value-minimum $\mathrm{Cq}$ value. These transformed quantities were based on geNorm and NormFinder calculations. BestKeeper and Bio-Rad Maestro software were selected for evaluation of the raw $\mathrm{Cq}$ values. A Student's t-test was used for statistical analysis of gene expression data using SPSS Software version 22 (IBM Corp.). $\mathrm{P}<0.05$ was considered to indicate a statistically significant difference. A variance analysis was performed using Microsoft Office Excel (Microsoft Corporation).

\section{Results}

Establishment of a KYDS-virus mice model. The KYDS mice model was commonly generated by the classical method of intraperitoneal injection with estradiol benzoate $(34,35)$. The body weight measurements of the mice in the KYDS model group were decreased significantly compared with the mice in the normal group from the 4 th to the 7 th day (Fig. S1A). The rectal temperatures of KYDS mice were also significantly decreased from the 2nd to the 7th day compared with the normal group (Fig. S1B). Spontaneous locomotor activity and swimming time were measured; in the KYDS mice, both values were decreased significantly compared with the mice in the normal group (Fig. S1C and D). We also measured the levels of serum steroid hormones (estradiol and progesterone) and thyroid hormones (T3 and T4) by XMAP-technology in a flow cytometry-based Luminex 200 instrument. The levels of estradiol in the mice in the KYDS model group were increased significantly compared with the mice in the normal group (Fig. S2A), but the expression levels of progesterone and T4 were significantly decreased in the KYDS mice, compared with the mice in the normal group (Fig. S2B and D). These data suggested that the KYDS model was established successfully. The data also suggest the presence of typical KYDS symptoms, including mental fatigue, lumbar debility, chill sensations and cold limbs. A total of 14 days post-treatment, the body weight and rectal temperature values in the KYDS-virus group were significantly decreased compared 


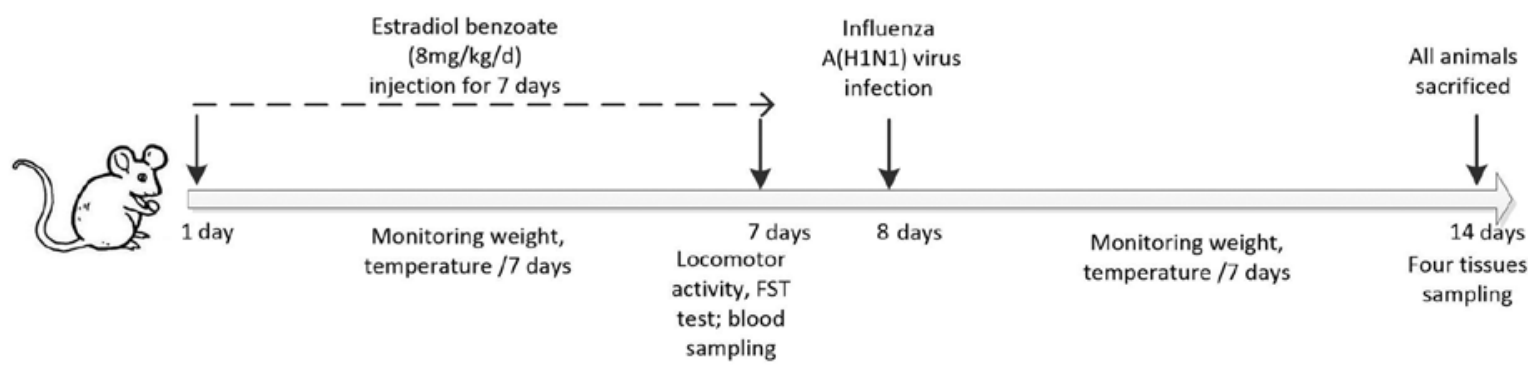

Figure 1. Schematic illustration of the experimental timeline.

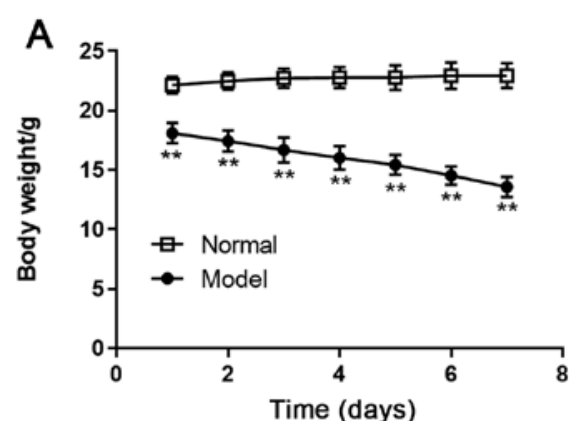

C

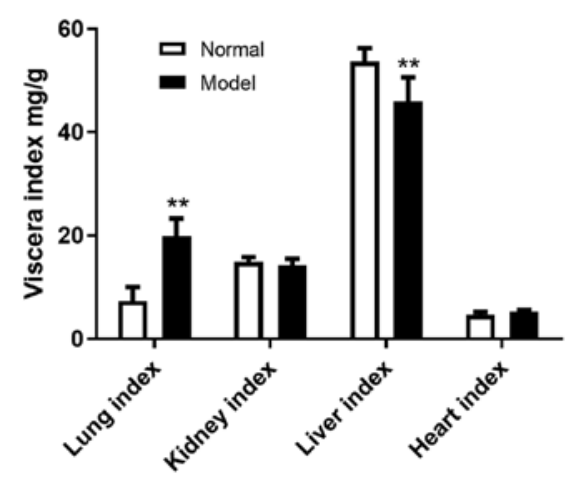

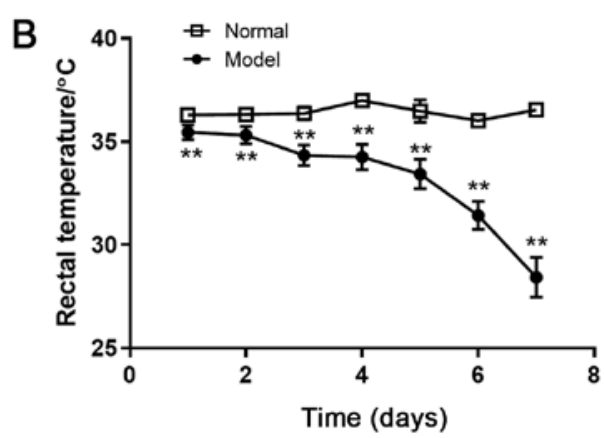

D

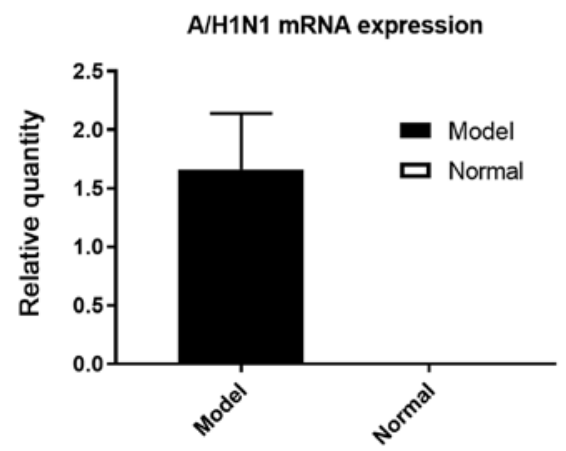

Figure 2. Assessment of the KYDS-virus model. (A) Weight and (B) rectal temperature were measured following establishment of the KYDS-virus model. (C) Visceral indices of different organs in mice. (D) Relative quantity of A/H1N1 mRNA expression. ${ }^{* *} \mathrm{P}<0.01$ vs. normal control. KYDS, Kidney-Yang deficiency syndrome; A/H1N1, influenza A virus subtype H1N1.

with the normal control group from day 1-7 following inoculation with the $\mathrm{A} / \mathrm{H} 1 \mathrm{~N} 1$ virus $(\mathrm{P}<0.01$; Fig. $2 \mathrm{~A}$ and $\mathrm{B})$. As shown in Fig. 2C, compared with the normal group, the model group liver index decreased significantly $(\mathrm{P}<0.01)$, whereas the lung index increased significantly $(\mathrm{P}<0.01)$. A/H1N1 virus mRNA expression was also assessed. Total RNA was isolated from lung and converted into cDNA, and the relative expression of $\mathrm{A} / \mathrm{H} 1 \mathrm{~N} 1$ $\mathrm{M}$ gene RNA was determined using qPCR and compared with the normal group (Fig. 2D). These results confirmed that a KYDS-virus mice model had been established successfully.

Expression profiles of candidate reference genes. For the evaluation of the expression of the KYDS-virus infection patterns, the 10 most frequently used and recommended candidate reference genes from literature were selected $(17,20,22,28,29)$. Following the qPCR assays, the performance of each amplification primer set was examined. For all reactions, the range of amplification efficiency was 99.0-99.9\%; and the variation of the standard curve for correlation coefficients $\left(\mathrm{R}^{2}\right)$ was 0.9913-0.9999 (Table I). All tested primer pairs were highly efficient and excellently correlated. There were no primer dimer formations, and only 1 peak was formed that confirmed the specificity of the amplification of the entire transcript by melt curve analysis. When the template was absent, no amplification was observed.

Both groups were comprised of 4 tissues and were assessed for the expression profiles of the candidate reference genes. It was observed that samples in different tissues exhibited inconsistent ranges of expression for each reference gene (Fig. 3). For the 10 candidate reference genes, expression levels are represented as $\mathrm{Cq}$ values, and varied between 13-29, with the majority ranging from 18-20. For every reference gene, a box plot was used to represent the $\mathrm{Cq}$ value distribution in different tissues.

geNorm algorithm. The gene expression stability (M) was calculated as the average pair-wise variation between all 

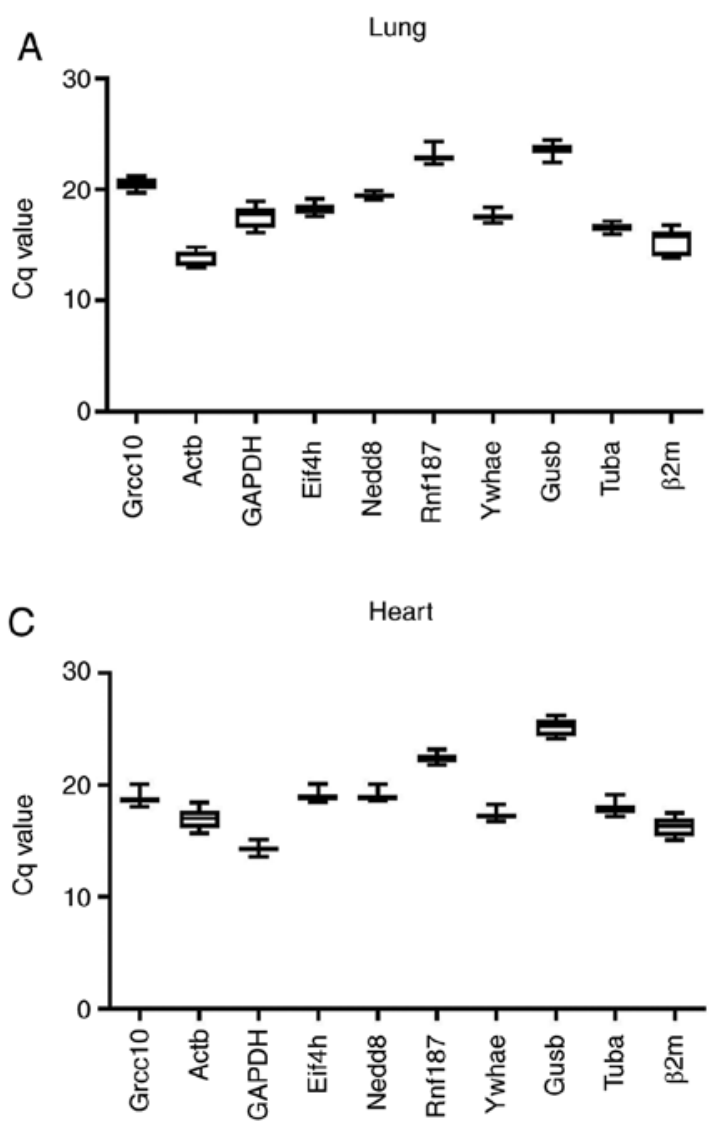

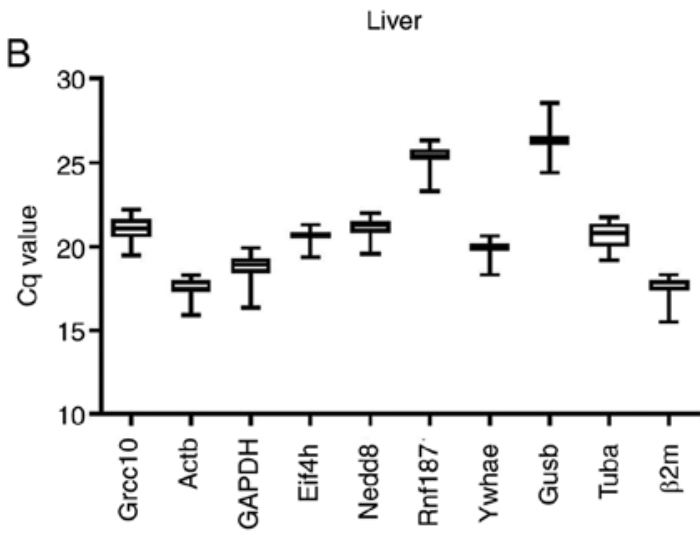

D

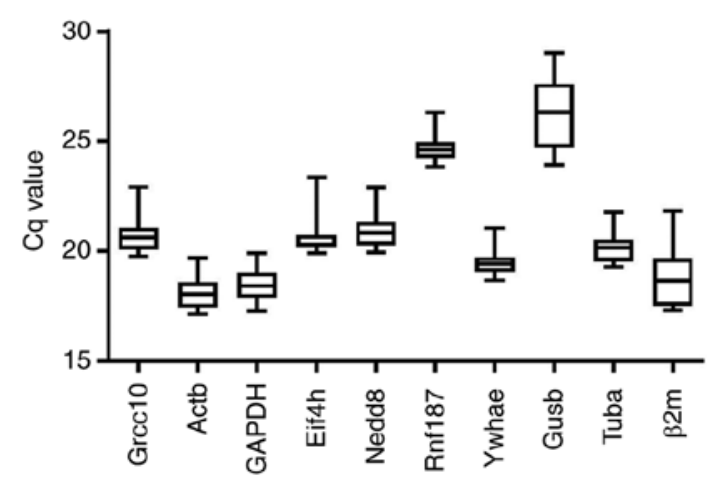

Figure 3. Distribution of Cq values for each reference gene. For (A) lung, (B) liver, (C) heart, and (D) kidney tissues, the distribution of the Cq values of the reference genes is represented using a box and whisker plots. Boxes represent the quartiles and medians, and the maximum and minimum values are represented by the whiskers. Cq, quantification cycle; Act $\beta$, $\beta$-actin; $\beta 2 \mathrm{~m}, \beta 2$ microglobulin; Gus $\beta$, $\beta$-glucuronidase; Tub $\alpha$, $\alpha$-tubulin; Grcc10, Gene rich cluster, C10 gene; Eif4h, eukaryotic translation initiation factor 4H; Rnf187, ring finger protein 187; Nedd8, neural precursor cell expressed, developmentally down-regulated gene 8; Ywhae, tyrosine 3-monooxygenase/tryptophan 5-monooxygenase activation protein, epsilon polypeptide.

examined genes, and geNorm software was selected for the analysis of expression stability of the candidate reference genes. The gene with the most parallel levels of expression in all samples without consideration of the conditions of experiment was considered the most stable reference gene and had the lowest $\mathrm{M}$ value, where an $\mathrm{M}$ value of $<1.5$ was a criterion for stability (Fig. 4).

For the reference genes assessed, the calculated average expression $M$ values using geNorm are presented in Table II. The reference genes in lung tissues with the lowest $\mathrm{M}$ values, and therefore considered the most stable, were Nedd8 $(M=0.42)$ and Tub $\alpha(M=0.436)$, whereas the least stable were GAPDH $(M=0.87)$ and Grcc10 $(M=0.73)$. Ywhae and Nedd8 were identified to be stable in the heart tissues, with $\mathrm{M}$ values of 0.416 and 0.418 , respectively, whereas $\beta 2 \mathrm{~m}(\mathrm{M}=0.988)$ exhibited the poorest stability. In liver tissue samples, Ywhae and Rnf187, with $\mathrm{M}$ values of 0.34 and 0.335 , respectively, were the most stable. In comparison, the most variable genes were $\operatorname{Gus} \beta(\mathrm{M}=0.636)$ and Grcc10 $(\mathrm{M}=0.564)$. For the kidney tissues, the genes considered to be the most stable were Tub $\alpha(M=0.529)$ and Ywhae $(\mathrm{M}=0.53)$. The least stable genes were $\beta 2 \mathrm{~m}$ and $\mathrm{Gus} \beta$ $(\mathrm{M}=1.532$ and 1.358 , respectively).

NormFinder algorithm. For the calculation of $\mathrm{M}$ value of the reference genes, NormFinder was used. NormFinder performs separate analysis of sample subgroups as a mathematical model, and also evaluates both inter- and intragroup expression variations. The genes with the lowest $\mathrm{M}$ value were considered the most stable and thus suitable for use as reference genes for such specific experimental conditions (Fig. 5).

A total of 3 genes were ranked with peak values by NormFinder (Table II). In the lung tissues, the 3 most stable genes were Nedd8, Ywhae, and Tuba; in the heart tissue, Nedd8, Ywhae, and Grcc10; in the liver tissue, Rnf187, Act $\beta$, and Nedd8; and in the kidney tissue, Tub $\alpha$, Ywhae, and Rnf187. The least stable genes, as determined by NormFinder, were the same as those identified using geNorm: In the liver tissue, they were Grcc10 and GAPDH; in the heart tissue, they were $\operatorname{Act} \beta$ and $\beta 2 \mathrm{~m}$; and in the kidney tissue, they were Gus $\beta$ and $\beta 2 \mathrm{~m}$.

BestKeeper algorithm. In regard to the gene-correlation analysis of candidate gene pairs, the expression standard of reference genes was assessed using BestKeeper software, using the grading of the standard deviation \pm crossing point $(\mathrm{SD} \pm \mathrm{CP})$. The genes with the lowest $\mathrm{SD}$ values were considered the most stable by this algorithm, and a grading of SD value $<1$ was considered an acceptable range of variation (Fig. 6).

As shown in Table II, the genes considered most stable using the BestKeeper algorithm were Nedd8 and Ywhae in the lung and heart tissue. Eif4h exhibited the lowest SD values in the liver 

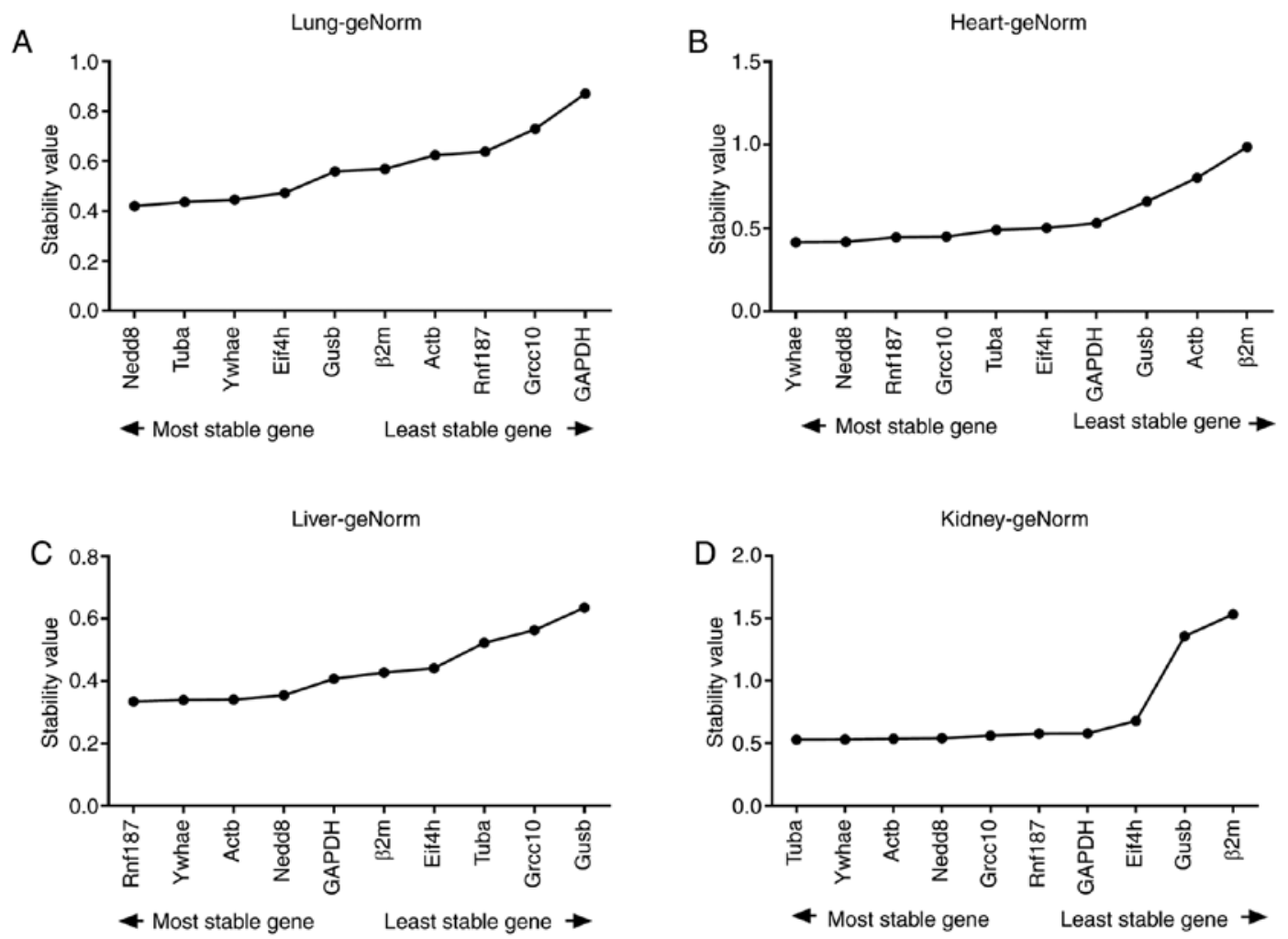

Figure 4. Average expression stability evaluated by GeNorm. For (A) lung tissue, (B) heart tissue, (C) liver tissue, and (D) kidney tissue under variable conditions, the $M$ values and grading are designated for mice. $M$, GeNorm-evaluated average expression stability; Act $\beta, \beta$-actin; $\beta 2 \mathrm{~m}, \beta 2 \mathrm{microglobulin}$; Gus $\beta$, $\beta$-glucuronidase; Tub $\alpha, \alpha$-tubulin; Grcc10, Gene rich cluster, $\mathrm{C} 10$ gene; Eif4h, eukaryotic translation initiation factor 4H; Rnf 187 , ring finger protein 187 ; Nedd8, neural precursor cell expressed, developmentally down-regulated gene 8; Ywhae, tyrosine 3-monooxygenase/tryptophan 5-monooxygenase activation protein, epsilon polypeptide.
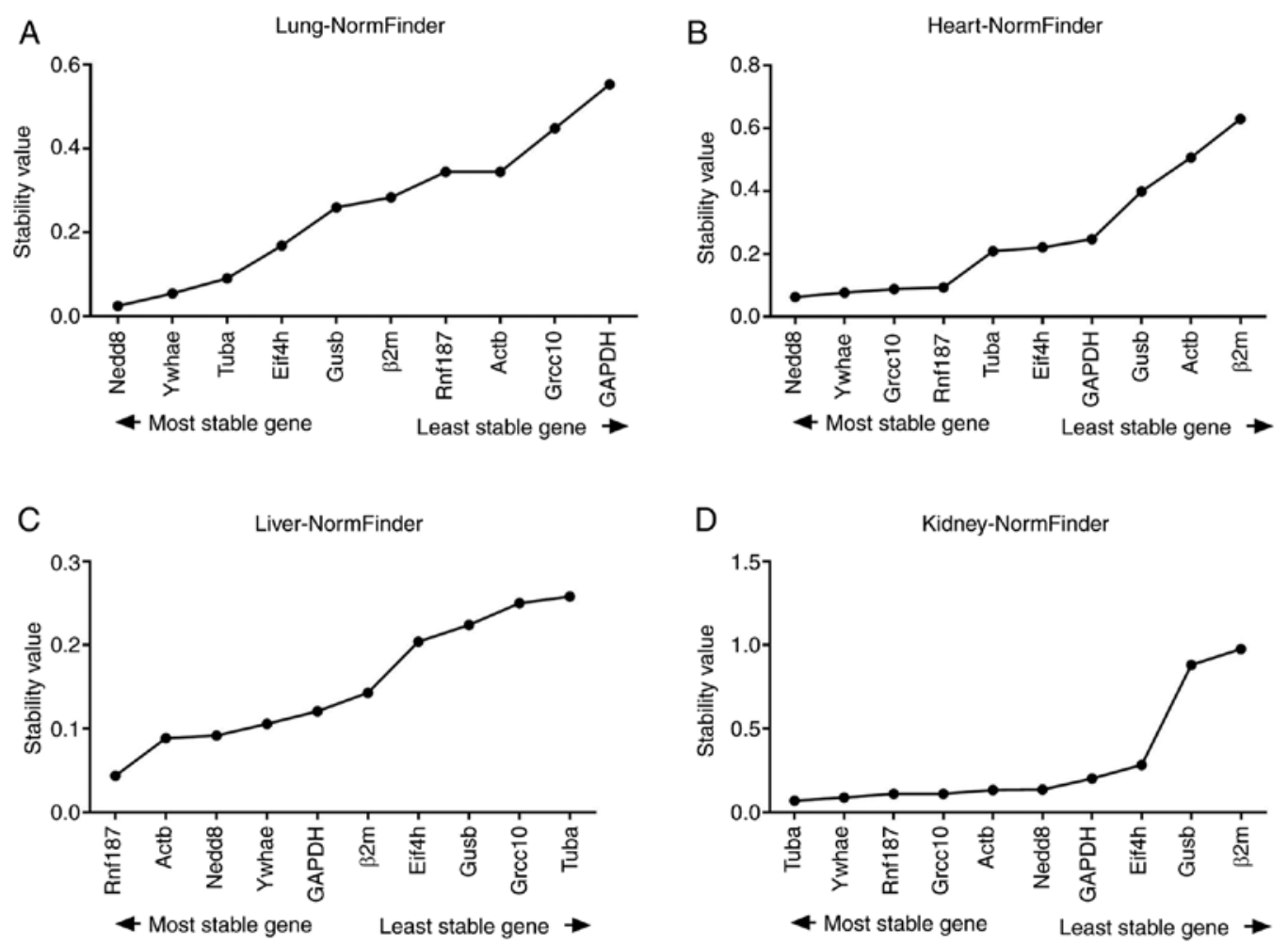

Figure 5. Average expression stability evaluated by NormFinder. For (A) lung tissue, (B) heart tissue, (C) liver tissue, and (D) kidney tissue under variable conditions, the $\mathrm{M}$ values and grading are designated for mice. $\mathrm{M}$, NormFinder-evaluated average expression stability; Act $\beta, \beta$-actin; $\beta 2 \mathrm{~m}, \beta 2 \mathrm{microglobulin}$; Gus $\beta$, $\beta$-glucuronidase; Tub $\alpha, \alpha$-tubulin; Grcc10, Gene rich cluster, $\mathrm{C} 10$ gene; Eif4h, eukaryotic translation initiation factor 4H; Rnf 187 , ring finger protein 187; Nedd8, neural precursor cell expressed, developmentally down-regulated gene 8; Ywhae, tyrosine 3-monooxygenase/tryptophan 5-monooxygenase activation protein, epsilon polypeptide. 
Table II. Analysis of gene expression in the KYDS-virus mouse model using geNorm, NormFinder, BestKeeper, and Bio-Rad CFX Maestro ${ }^{\mathrm{TM}}$ software programs.

\begin{tabular}{|c|c|c|c|c|c|c|c|c|c|c|}
\hline \multirow[b]{3}{*}{ Tissue } & \multirow[b]{3}{*}{ Rank } & \multirow{2}{*}{\multicolumn{2}{|c|}{ geNorm }} & \multicolumn{2}{|c|}{ NormFinder } & \multicolumn{2}{|c|}{ BestKeeper } & \multicolumn{2}{|c|}{ Bio-Rad } & \multirow{3}{*}{$\begin{array}{l}\text { Comprehensive } \\
\text { ranking by geoMean }\end{array}$} \\
\hline & & & & & Stability & & std dev & & Stability & \\
\hline & & Gene & M & Gene & value & Gene & {$[ \pm \mathrm{CP}]$} & Gene & $(\operatorname{Ln}(1 / \operatorname{AvgM}))$ & \\
\hline \multirow[t]{10}{*}{ Lung } & 1 & Nedd8 & 0.420 & Nedd8 & 0.025 & Nedd8 & 0.196 & Tuba & 1.815 & Nedd8 \\
\hline & 2 & Tuba & 0.436 & Ywhae & 0.055 & Ywhae & 0.278 & Ywhae & 1.815 & Ywhae \\
\hline & 3 & Ywhae & 0.445 & Tub $\alpha$ & 0.091 & Tub $\alpha$ & 0.312 & Nedd 8 & 1.653 & Tuba \\
\hline & 4 & Eif4h & 0.473 & Eif4h & 0.169 & Rnf187 & 0.355 & Eif4h & 1.512 & Eif4h \\
\hline & 5 & Gus $\beta$ & 0.559 & Gus $\beta$ & 0.260 & Eif4h & 0.383 & Gus $\beta$ & 1.277 & Gus $\beta$ \\
\hline & 6 & $\beta 2 \mathrm{~m}$ & 0.569 & $\beta 2 \mathrm{~m}$ & 0.284 & Gus $\beta$ & 0.431 & $\operatorname{Act} \beta$ & 1.089 & Rnf 187 \\
\hline & 7 & Act $\beta$ & 0.624 & Rnf187 & 0.345 & Grec10 & 0.432 & GAPDH & 0.888 & $\operatorname{Act} \beta$ \\
\hline & 8 & Rnf187 & 0.638 & $\operatorname{Act} \beta$ & 0.345 & $\operatorname{Act} \beta$ & 0.624 & Rnf187 & 0.733 & $\beta 2 \mathrm{~m}$ \\
\hline & 9 & Grec10 & 0.730 & Grce10 & 0.449 & GAPDH & 0.874 & $\beta 2 \mathrm{~m}$ & 0.603 & Grec10 \\
\hline & 10 & GAPDH & 0.870 & GAPDH & 0.554 & $\beta 2 \mathrm{~m}$ & 1.025 & Grec10 & 0.483 & GAPDH \\
\hline \multirow[t]{10}{*}{ Heart } & 1 & Ywhae & 0.416 & Nedd8 & 0.063 & Nedd8 & 0.182 & Nedd8 & 1.865 & Nedd8 \\
\hline & 2 & Nedd8 & 0.418 & Ywhae & 0.077 & Ywhae & 0.232 & Grec10 & 1.865 & Ywhae \\
\hline & 3 & Rnf187 & 0.446 & Grcc10 & 0.088 & Eif4h & 0.248 & Ywhae & 1.706 & Grec10 \\
\hline & 4 & Grcc10 & 0.449 & Rnf187 & 0.094 & Grec10 & 0.257 & Rnf187 & 1.513 & Rnf187 \\
\hline & 5 & Tub $\alpha$ & 0.490 & Tub $\alpha$ & 0.209 & GAPDH & 0.263 & Eif4h & 1.349 & Eif4h \\
\hline & 6 & Eif4h & 0.502 & Eif4h & 0.221 & Rnf187 & 0.325 & GAPDH & 1.246 & Tub $\alpha$ \\
\hline & 7 & GAPDH & 0.531 & GAPDH & 0.247 & Tub $\alpha$ & 0.446 & Tub $\alpha$ & 1.130 & GAPDH \\
\hline & 8 & Gus $\beta$ & 0.660 & Gus $\beta$ & 0.399 & $\beta 2 \mathrm{~m}$ & 0.644 & Gus $\beta$ & 0.932 & Gus $\beta$ \\
\hline & 9 & $\operatorname{Act} \beta$ & 0.803 & $\operatorname{Act} \beta$ & 0.507 & Gus $\beta$ & 0.660 & Act $\beta$ & 0.765 & $\operatorname{Act} \beta$ \\
\hline & 10 & $\beta 2 \mathrm{~m}$ & 0.988 & $\beta 2 \mathrm{~m}$ & 0.629 & $\operatorname{Act} \beta$ & 0.828 & $\beta 2 \mathrm{~m}$ & 0.561 & $\beta 2 \mathrm{~m}$ \\
\hline \multirow[t]{10}{*}{ Liver } & 1 & Rnf187 & 0.335 & Rnf187 & 0.044 & Eif4h & 0.327 & Ywhae & 1.967 & Rnf187 \\
\hline & 2 & Ywhae & 0.34 & Act $\beta$ & 0.089 & Ywhae & 0.343 & $\operatorname{Act} \beta$ & 1.967 & Ywhae \\
\hline & 3 & $\operatorname{Act} \beta$ & 0.341 & Nedd8 & 0.092 & $\operatorname{Act} \beta$ & 0.395 & Rnf187 & 1.733 & $\operatorname{Act} \beta$ \\
\hline & 4 & Nedd8 & 0.355 & Ywhae & 0.106 & Rnf187 & 0.464 & Nedd8 & 1.528 & Eif4h \\
\hline & 5 & GAPDH & 0.408 & GAPDH & 0.121 & Gus $\beta$ & 0.468 & GAPDH & 1.406 & Nedd8 \\
\hline & 6 & $\beta 2 \mathrm{~m}$ & 0.428 & $\beta 2 \mathrm{~m}$ & 0.143 & $\beta 2 \mathrm{~m}$ & 0.471 & Eif4h & 1.301 & GAPDH \\
\hline & 7 & Eif4h & 0.442 & Eif4h & 0.204 & Nedd8 & 0.488 & $\beta 2 \mathrm{~m}$ & 1.219 & $\beta 2 \mathrm{~m}$ \\
\hline & 8 & Tub $\alpha$ & 0.523 & Gus $\beta$ & 0.224 & GAPDH & 0.579 & Grcc 10 & 1.124 & Gus $\beta$ \\
\hline & 9 & Grec10 & 0.564 & Grcc10 & 0.250 & Grce10 & 0.651 & Tub $\alpha$ & 1.019 & Grcc10 \\
\hline & 10 & Gus $\beta$ & 0.636 & Tuba & 0.258 & Tub $\alpha$ & 0.705 & Gus $\beta$ & 0.878 & Tub $\alpha$ \\
\hline \multirow[t]{10}{*}{ Kidney } & 1 & Tuba & 0.529 & Tub $\alpha$ & 0.071 & Ywhae & 0.429 & Tuba & 1.593 & Tub $\alpha$ \\
\hline & 2 & Ywhae & 0.530 & Ywhae & 0.089 & Rnf187 & 0.459 & $\operatorname{Act} \beta$ & 1.593 & Ywhae \\
\hline & 3 & $\operatorname{Act} \beta$ & 0.536 & Rnf187 & 0.112 & Tub $\alpha$ & 0.496 & Nedd8 & 1.383 & $\operatorname{Act} \beta$ \\
\hline & 4 & Nedd8 & 0.540 & Grcc10 & 0.112 & Eif4h & 0.505 & Grec10 & 1.338 & Rnf 187 \\
\hline & 5 & Grcc10 & 0.560 & $\operatorname{Act} \beta$ & 0.134 & Nedd8 & 0.549 & Ywhae & 1.290 & Nedd8 \\
\hline & 6 & Rnf187 & 0.577 & Nedd8 & 0.137 & Grec10 & 0.555 & GAPDH & 1.234 & Grec10 \\
\hline & 7 & GAPDH & 0.580 & GAPDH & 0.203 & GAPDH & 0.574 & Rnf187 & 1.190 & Eif4h \\
\hline & 8 & Eif4h & 0.679 & Eif4h & 0.285 & Act $\beta b$ & 0.584 & Eif4h & 1.042 & GAPDH \\
\hline & 9 & Gus $\beta$ & 1.358 & Gus $\beta$ & 0.881 & $\beta 2 \mathrm{~m}$ & 1.085 & Gus $\beta$ & 0.608 & Gus $\beta$ \\
\hline & 10 & $\beta 2 \mathrm{~m}$ & 1.532 & $\beta 2 \mathrm{~m}$ & 0.975 & Gus $\beta$ & 1.330 & $\beta 2 \mathrm{~m}$ & 0.298 & $\beta 2 \mathrm{~m}$ \\
\hline
\end{tabular}

geoMean, geometric mean; CP, crossing point; KYDS, Kidney-yang deficiency syndrome. Grading of expression stability of candidate reference gene was dependent on the geoMean of results obtained by the different software programs. The suitability of candidate genes is ranked.

tissue samples, and Ywhae and Rnf187 were the most stable in the kidney tissue. Following the analysis of all samples, Ywhae had the lowest SD values and was considered the most stable.
Analysis using the CFX Maestro software. Bio-Rad CFX Maestro (v.1.1) software is based on the geNorm algorithm (36), but optimized for certain functions. The genes considered 


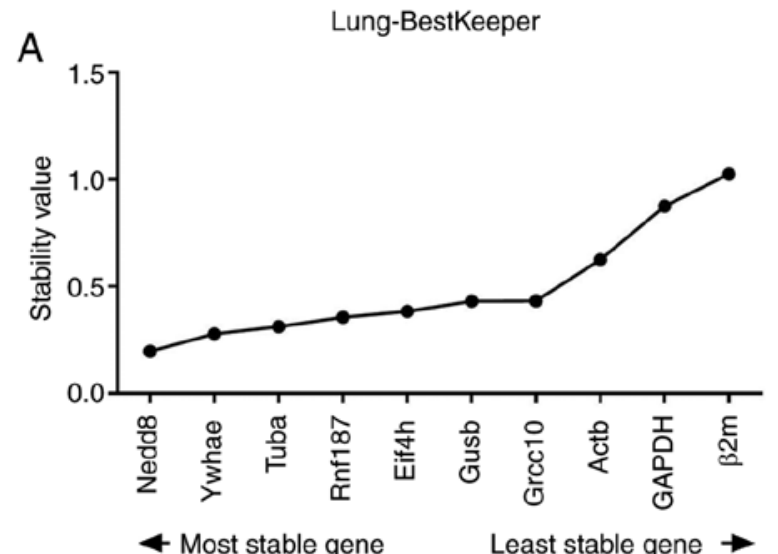

C

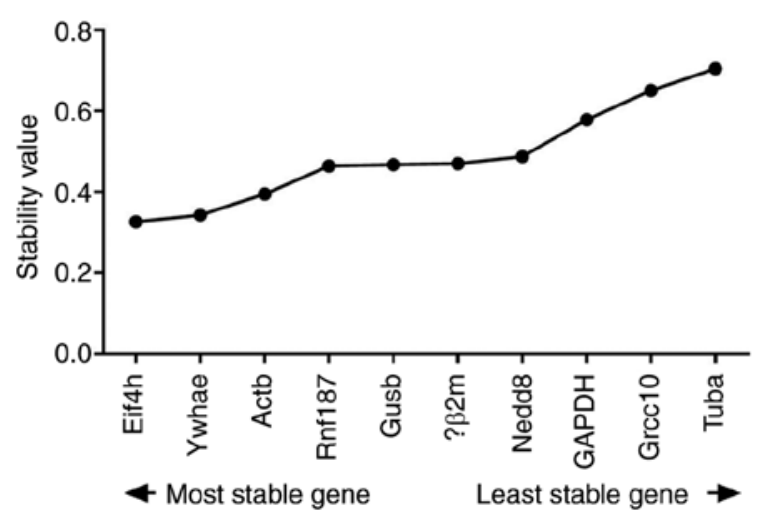

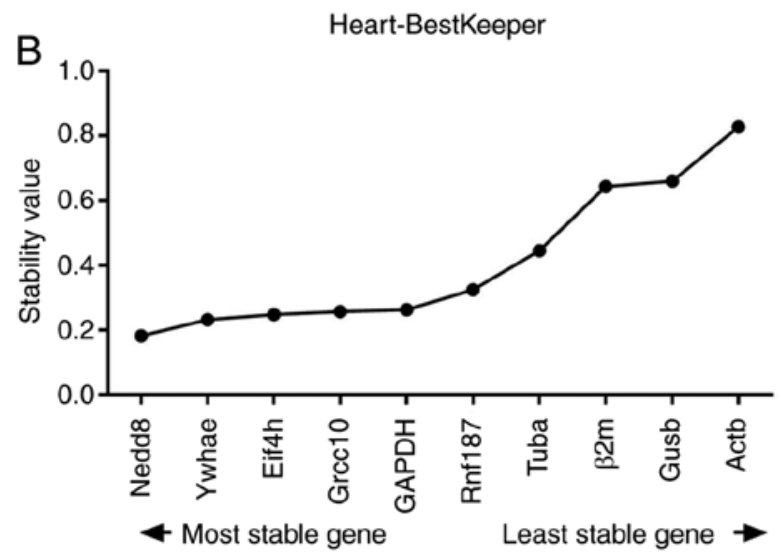

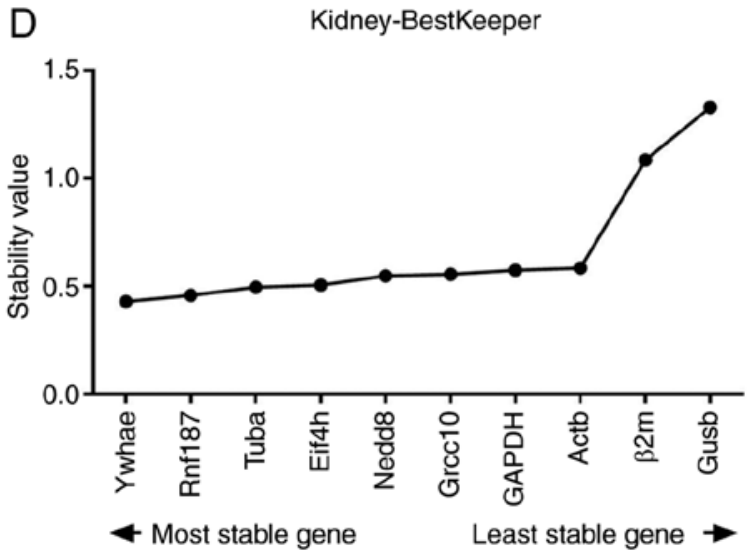

Figure 6. Average expression stability evaluated using BestKeeper. SD values and grading are represented for mice under variable settings. (A) Lung tissue, (B) heart tissue, (C) liver tissue, and (D) kidney tissue. Stability was calculated using the following formula: SD [ $\pm \mathrm{CP}]$. SD, standard deviation; $\mathrm{CP}$, crossing point; Act $\beta$, $\beta$-actin; $\beta 2 \mathrm{~m}, \beta 2$ microglobulin; Gus $\beta$, $\beta$-glucuronidase; Tub $\alpha, \alpha$-tubulin; Grcc10, Gene rich cluster, C10 gene; Eif4h, eukaryotic translation initiation factor $4 \mathrm{H}$; Rnf187, ring finger protein 187; Nedd8, neural precursor cell expressed, developmentally down-regulated gene 8; Ywhae, tyrosine 3-monooxygenase/tryptophan 5-monooxygenase activation protein, epsilon polypeptide.

Table III. Expression stability of the candidate reference genes following treatment of the KYDS-virus mice ranked based on the geoMean of the gene grade in every tissue. The suitability of the candidate genes are ranked from top to bottom.

\begin{tabular}{lccccc}
\hline Gene & $\begin{array}{c}\text { Comprehensive } \\
\text { ranking by } \\
\text { geoMean }\end{array}$ & $\begin{array}{c}\text { Rank } \\
\text { in lung }\end{array}$ & $\begin{array}{c}\text { Rank } \\
\text { in heart }\end{array}$ & $\begin{array}{c}\text { Rank } \\
\text { in liver }\end{array}$ & $\begin{array}{c}\text { Rank } \\
\text { in kidney }\end{array}$ \\
\hline Ywhae & 1 & 2 & 2 & 2 & 2 \\
Nedd 8 & 2 & 1 & 1 & 5 & 5 \\
Rnf187 & 3 & 6 & 4 & 1 & 4 \\
Tub $\alpha$ & 4 & 3 & 6 & 10 & 1 \\
Eif4h & 5 & 4 & 5 & 4 & 7 \\
Act $\beta$ & 6 & 7 & 9 & 3 & 3 \\
Grcc10 & 7 & 9 & 3 & 9 & 6 \\
Gus $\beta$ & 8 & 5 & 8 & 8 & 9 \\
GAPDH & 9 & 10 & 7 & 6 & 8 \\
$\beta 2 m$ & 10 & 8 & 10 & 7 & 10 \\
\hline
\end{tabular}

the most stable exhibited higher $[\operatorname{Ln}(1 / \operatorname{Avg} M)]$ values, where values $>1$ were considered as acceptable (Fig. 7).
The results of analysis from CFX Maestro software are presented in Table II. Tub $\alpha$ was considered the most stable reference gene in lung and kidney tissues. Nedd8 and Grcc10 $[\operatorname{Ln}(1 / \operatorname{AvgM})=1.8652]$ were considered the most stable for heart tissue, and in the liver tissue, Ywhae and Act $\beta$ $[\operatorname{Ln}(1 / \operatorname{Avg} M)=1.9668]$, were considered the most stable genes.

Ranking order of the most stable genes. In order to identify reference genes that would be appropriate for various tissue types following KYDS-virus treatment compared with the normal group, NormFinder, geNorm, BestKeeper, and CFX Maestro software were used to determine the stability of each gene. Due to the dependence on analytical procedures as well as different algorithms, these statistical programs are considered more acceptable to create distinct levels of reference genes ranks.

In relation to their geoMean ranking positions, genes were ranked from 1-10 (Table III). Ywhae was positioned as peak stable gene across all four tissues, followed by Nedd8 and Rnf187, with a low-ranking mean value (1.74, 2.19 and 3.10 , respectively). GAPDH and $\beta 2 \mathrm{~m}$ were considered the least stable according to all 4 algorithms, with a higher ranking mean value (7.87 and 8.91, respectively).

Validation of the selected reference genes. For validation of the consistency of selected reference genes, the expression of 

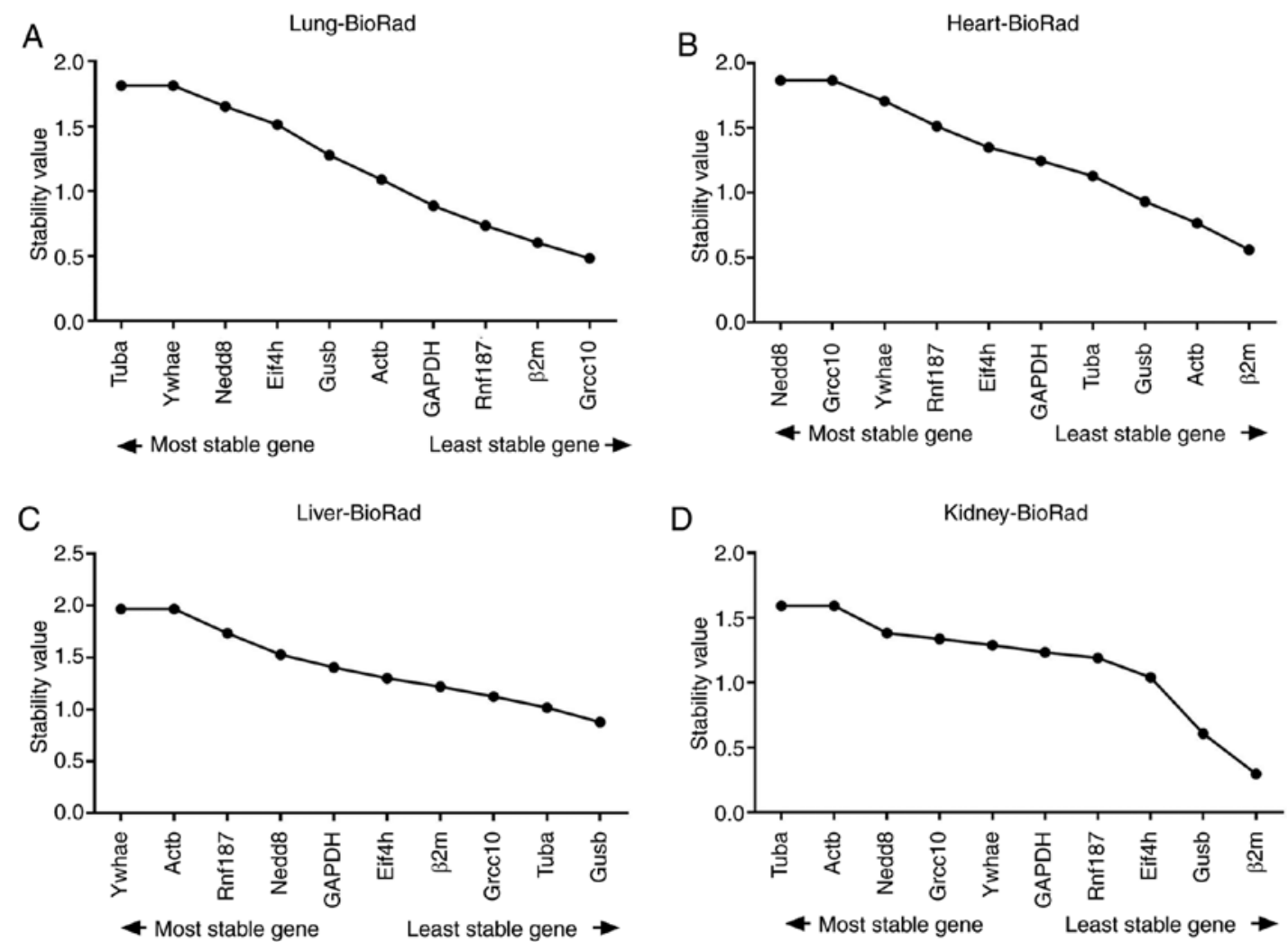

Figure 7. Average expression stability evaluated using Bio-Rad CFX Maestro ${ }^{\mathrm{TM}}$ software. Stability values and rankings are indicated for mice under different conditions for (A) lung tissue, (B) heart tissue, (C) liver tissue and (D) kidney tissue. Average expression stability was calculated as follows: [Ln(1/AvgM)]. M, expression stability; Act $\beta, \beta$-actin; $\beta 2 \mathrm{~m}, \beta 2$ microglobulin; Gus $\beta, \beta$-glucuronidase; Tub $\alpha, \alpha$-tubulin; Grcc10, Gene rich cluster, C10 gene; Eif4h, eukaryotic translation initiation factor $4 \mathrm{H}$; Rnf 187, ring finger protein 187; Nedd8, neural precursor cell expressed, developmentally down-regulated gene 8; Ywhae, tyrosine 3-monooxygenase/tryptophan 5-monooxygenase activation protein, epsilon polypeptide.
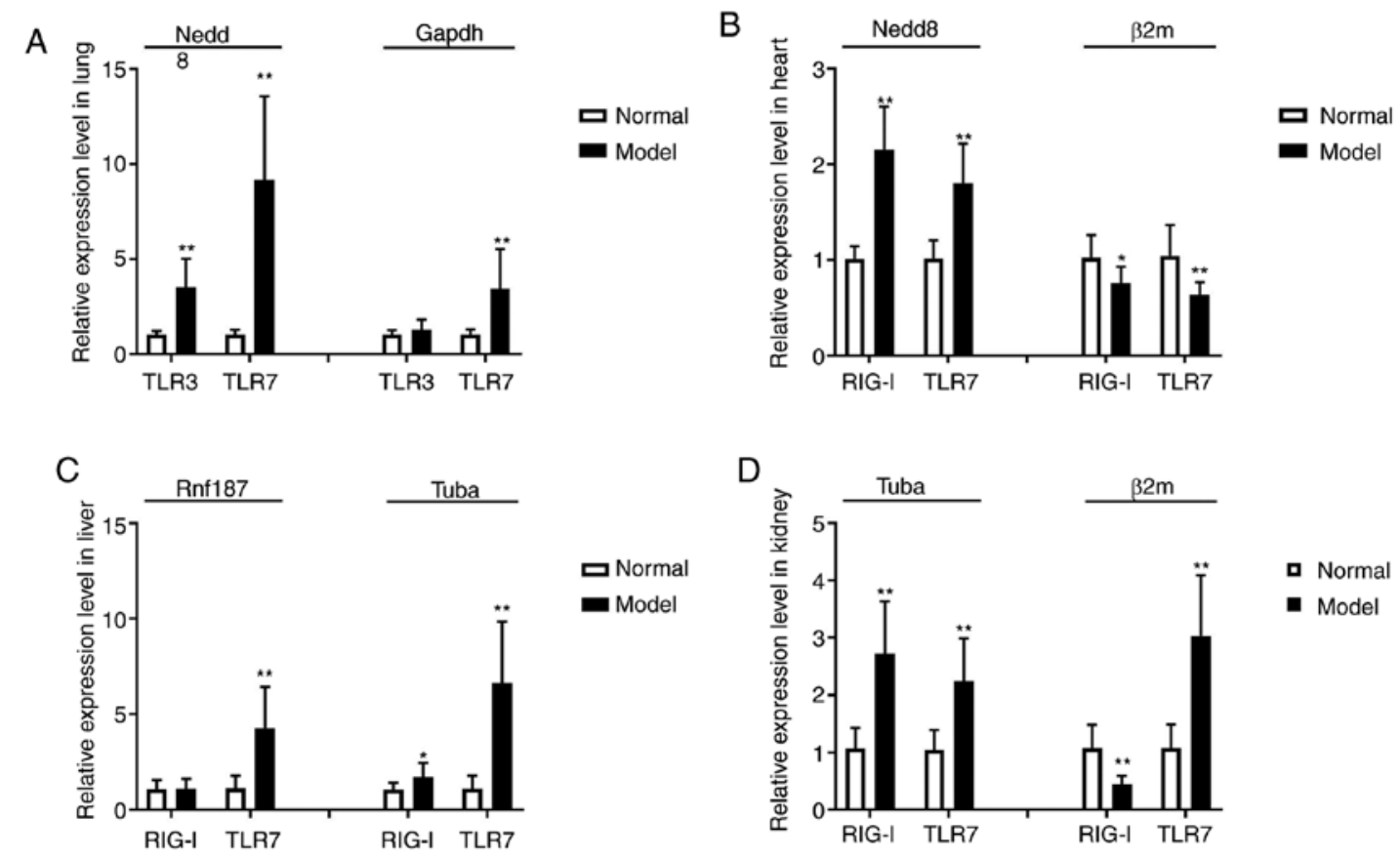

Figure 8. Relative mRNA expression levels of TLR3, TLR7 and RIG-I in (A) lung, (B) heart, (C) liver and (D) kidney tissues of the normal and model mice. Expression was normalized to the normal mice. ${ }^{*} \mathrm{P}<0.05$ and ${ }^{* *} \mathrm{P}<0.01$ vs. normal control. TLR, toll-like receptor; RIG-I, retinoic acid inducible gene-I.

these genes was determined in the KYDS-virus samples. The analysis of comparative expression levels of the target genes was performed for validation of reference genes selection.
The expression levels of TLR3, TLR7, and cytosolic RIG-I, which serve important roles in the innate immune response of the host, were examined. They all belong to host pattern 
recognition receptors and recognize pathogen-associated molecular patterns during viral infection $(37,38)$. Recognition of a pathogen-associated molecular pattern enhances the transcription factor for interferon regulation and stimulates NF- $\mathrm{KB}$, which in turn is responsible for the secretion of inflammatory mediators, such as cytokines and chemokines. Therefore, the expression levels of TLR3, TLR7, and RIG-I in the 4 types of tissues were assessed (Fig. 8). Using Nedd8 expression levels in the lung and heart, Rnf187 expression levels in the liver and Tuba expression levels in the kidney as reference genes, there was a significant increase in TLR3 and TLR7 expression $(\mathrm{P}<0.01)$ in the lungs, an increase of TLR7 expression in liver, and increased RIG-I and TLR7 expression in heart and kidney $(\mathrm{P}<0.01)$ following infection (Fig. 8A). This data confirms that the selected reference genes are reliable in each of the tissues. Alternatively, the references genes considered to be the least stable were: GAPDH for the lung samples; $\beta 2 \mathrm{~m}$ in the heart and kidney; and Tubo in the liver (Fig. 8B). Using these reference genes, no marked changes in TLR3 expression were observed in the lung tissue, RIG-I and TLR7 expression was considered decreased in the heart tissue samples $(\mathrm{P}<0.05$ or $\mathrm{P}<0.01$; Fig. $8 \mathrm{~B}$ ), and RIG-I either exhibited a reverse in the direction of expression in kidney tissue (Fig. 8D; $\mathrm{P}<0.01$ ), or was not altered significantly in liver tissue (Fig. 8D; $\mathrm{P}<0.05$ ). For this experiment in qPCR analysis, the appropriate reference gene was shown to be paramount to obtain reliable results when studying the expression of genes in the assessment of KYDS-virus treatment.

\section{Discussion}

In molecular biology, gene expression analysis is one of the most frequently used strategies to study expression of genes. Its accuracy and versatility make qPCR suitable for analysis of relative gene expression. However, the results obtained from qPCR are strongly affected by the stability of the reference gene selected for normalization of gene expression data; therefore, it is crucial to select stably expressed genes as internal references.

In the present study, a screen for suitable genes for data normalization in a KYDS-virus model was performed in lung, heart, liver, and kidney tissues. The expression stability of 10 housekeeping genes (Act $\beta, \beta 2 \mathrm{~m}$, GAPDH, Gus $\beta$, Tub $\alpha$, Grcc10, Eif4h, Rnf187, Nedd8 and Ywhae) were analyzed using 4 software packages: geNorm; NormFinder; BestKeeper; and CFX Maestro software. The 4 statistical algorithms have been used to select and validate reference genes for qPCR data normalization across a variety of tissues, species and different treatments (39-41). Grcc10, Eif4h, Rnf187, Nedd8 and Ywhae are all considered consistently and highly expressed genes that can be used as reference controls in expression-profiling analysis when using RNA-seq in various tissues, including lung tissue of mice $(28,42)$. Tub $\alpha$ has been identified in almost all organisms $(43,44)$; it polymerizes into microtubules, a major component of the eukaryotic cytoskeleton (45). $\beta 2 \mathrm{~m}$ is a component of the MHC class I molecule (46); it is necessary for cell surface expression of MHC class I and stability of the peptide binding groove. $\beta$-glucuronidase (Gus $\beta$ ) is a member of the glycosidase family and is involved in the breakdown of glycosaminoglycan (47). Act $\beta$ is a actin cytoskeleton protein, and is crucial for maintaining cell morphology. GAPDH is associated with the metabolism of carbohydrates (48), but is also important in several other processes. The present study evaluated 10 frequently used reference genes, which are involved in basic biochemical metabolic processes in the majority of cells. However, in most studies GAPDH and Act $\beta$ show variability under different experimental conditions in various types of cells and tissues (49). This is particularly true with infection with the influenza virus, which inhibits cellular synthesis of macromolecular compounds (shut-off) and results in whole body changes to gene expression $(29,50)$, and affects the mRNA expression levels of several other genes. Our previous study showed that traditional reference genes, for example GAPDH or Act $\beta$, are not stable in lung tissues of a mouse model of KYDS following infection with influenza A virus compared with normal control mice. It also has been reported that the expression levels of the Act $\beta$ and GAPDH as housekeeping genes are significantly affected by influenza virus infection, and therefore are not suitable as reference genes for normalization (51). Different statistical algorithms generate varied results for stability ranking in different tissues, and this was observed in the present study where, in KYDS mice tissues, the 3 statistical algorithms geNorm, CFX Maestro, and NormFinder recommended the most stable reference gene as Tuba. However, Ywhae was considered the most stable gene by BestKeeper. Different statistical algorithms have different bases for ranking the stability of reference genes, and this underlies the variability between the results. geNorm analysis depends on the similarity in the ratio of expression between the 2 best internal control genes amongst all genes selected for analysis. By contrast, in NormFinder, both inter- and intra-group variation is combined in for calculation of a stability value. The expression standard of reference genes was ranked by BestKeeper software with the grading of the standard deviation $[ \pm \mathrm{CP}]$ of $\mathrm{Cq}$ values. This variability in the results represents the difference in the manner in which the programs determine stability. The use of multiple techniques improves the accuracy of stability of reference genes and integration of data to produce an absolute ranking, thereby improving the reliability of the results. Therefore, it is suggested to use algorithms together, rather than relying on a single one.

The present study showed that different reference genes are recommended for different conditions, such as different tissues and different treatment groups. Therefore, it is concluded that the ideal reference gene for specific conditions varies. As the suitability of reference genes varies, it is important to verify the suitability of the reference gene for normalization, and determine the degree of variability in expression, as this variability may underlie differences in expression. Alterations of TLR7, TLR3, and RIG-I were observed using the assessed reference genes in the KYDS-virus mouse model in our previous study, and the observed differences in expression of these genes may in fact be the result of variations in the expression of the reference genes. However, using a range of reference genes may result in false-negative results. In the present study, this phenomenon was observed when the data was normalized with a single reference gene. In different tissues, or treatment groups, the target genes expression appeared to be significantly different, which may affect the results. The data of the present study indicated that it 
is essential to determine and use validated reference genes to ensure stability of their expression for normalizing qPCR data. KYDS is a type of syndrome model used in order to mimic the high-risk, susceptible population in flu season. Following viral infection, mice in the KYDS-virus group demonstrated symptoms of infection, with some reaching critical condition. It was identified that the body weight and rectal temperature values in the KYDS-virus model group decreased significantly $(\mathrm{P}<0.01)$. In the KYDS-virus group, certain mice experienced serious symptoms, with some mice succumbing after 7 days. The changes in KYDS condition in individual mice were minor during the short study period. Therefore, the changes in KYDS following viral infection in each mouse were not measured. In the present study, only normal and KYDS-virus groups were used; the lack of 'KYDS only' and 'virus only' groups represent a limitation of the study design. In future studies, comparison among more groups may produce more reliable reference results.

In conclusion, the present study was designed evaluate the effects of KYDS-virus in lung, heart, liver, and kidney tissues on the expression of several candidate reference genes used for normalization of gene expression when using qPCR in $\mathrm{BALB} / \mathrm{c}$ mice. The significance of using multiple software packages to obtain more reliable results was observed by using 4 algorithms, which yielded different results on the suitability of each gene in each tissue.

For individual tissues, there should be specifically selected reference genes, which should be determined following examination of the stability of several reference genes. Based on the results of the present study, the most suitable reference genes for each tissue assessed were Nedd8 in the lung and heart, Rnf187 in the liver, and Tub $\alpha$ in the kidney. Across all 4 tissues types, Ywhae and Nedd8 were identified to be the top 2 stable genes for KYDS mice infected with A/H1N1. By contrast, the least stable genes in all 4 tissues were GAPDH and $\beta 2 \mathrm{~m}$. The validation of the selected reference genes was shown using 3 target genes (TLR3, TLR7 and RIG-I) for certain experimental conditions. The present study highlights the importance of using a suitable reference gene to obtain reliable results when assessing gene expression. The present study provides a direction for designing future studies where gene expression is assessed, particularly for studies of KYDS combined with $\mathrm{A} / \mathrm{H} 1 \mathrm{~N} 1$ infection.

\section{Acknowledgements}

Not applicable.

\section{Funding}

This work was financially supported, in part, by grants from the National Natural Science Foundation of China (grant nos. 81873220 and 81774167), and Key Research and Development Program in Shandong Province (grant no. 2018CXGC1307).

\section{Availability of data and material}

The datasets used and/or analyzed during the present study are available from the corresponding author on reasonable request.

\section{Authors' contributions}

YY designed the study, performed the experiments and data analysis, and wrote the manuscript. YF and JY designed the study, performed the animal experiments and the data analysis. SF, SZ, RD and RR participated in performing the experiments and data analysis. SMAS and MA analyzed the target gene expressions and critically revised the manuscript for important intellectual content. All authors read and approved the final manuscript.

\section{Ethics approval and consent to participate}

All experimental procedures were performed in strict accordance with the guidelines for the care and use of laboratory animals of Shandong University of Traditional Chinese Medicine and were approved by the Ethics Committee of Laboratory Animals of Shandong University of Traditional Chinese Medicine (approval no. SDUTCM2018091901).

\section{Patient consent for publication}

Not applicable.

\section{Competing interests}

The authors declare that they have no competing interests.

\section{References}

1. Leong DT, Gupta A, Bai HF, Wan G, Yoong LF, Too HP, Chew FT and Hutmacher DW: Absolute quantification of gene expression in biomaterials research using real-time PCR. Biomaterials 28: 203-210, 2007.

2. Pfaffl MW: A new mathematical model for relative quantification in real-time RT-PCR. Nucleic Acids Res 29: e45, 2001.

3. Livak KJ and Schmittgen TD: Analysis of relative gene expression data using real-time quantitative PCR and the 2(-Delta Delta C(T)) method. Methods 25: 402-408, 2001.

4. Bustin SA, Benes V, Garson JA, Hellemans J, Huggett J, Kubista M, Mueller R, Nolan T, Pfaffl MW, Shipley GL, et al: The MIQE guidelines: Minimum information for publication of quantitative real-time PCR experiments. Clin Chem 55: 611-622, 2009.

5. Udvardi MK, Czechowski T and Scheible WR: Eleven golden rules of quantitative RT-PCR. Plant Cell 20: 1736-1737, 2008.

6. Havelda Z, Várallyay É, Válóczi A and Burgyán J: Plant virus infection-induced persistent host gene downregulation in systemically infected leaves. Plant J 55: 278-288, 2008.

7. Taylor S, Wakem M, Dijkman G, Alsarraj M and Nguyen M: A practical approach to RT-qPCR-publishing data that conform to the MIQE guidelines. Methods 50: S1-S5, 2010.

8. Cox NJ and Subbarao K: Global epidemiology of influenza: Past and present. Annu Rev Med 51: 407-421, 2000.

9. Whitley RJ and Monto AS: Prevention and treatment of influenza in high-risk groups: Children, pregnant women, immunocompromised hosts, and nursing home residents. J Infect Dis 194 (Suppl 2): S133-S138, 2006.

10. Zelaya H, Alvarez S, Kitazawa $\mathrm{H}$ and Villena J: Respiratory antiviral immunity and immunobiotics: Beneficial effects on inflammation-coagulation interaction during influenza virus infection. Front Immunol 7: 633, 2016.

11. Chen Q: Experimental methodology of pharmacological research in traditional Chinese medicine. People's Health Publishing House, Beijing, 1993.

12. Huai-Chang F, Wei-hong L and Shi-hong Y: Study on the diagnosis of kidney-'Yang' deficiency by 2067 cases of epidemiological survery. LIshizhen Med Mater Med Res 21: 952-954, 2010.

13. Lu JB, Zhou RQ, Liu RR and Xue RH: Investigation and analysis of kidney deficiency and patterns in the elderly. J Shanghai Univ Tradit Chin Med 16: 22-23, 2002. 
14. Yin Z, Yue L, Li X, Chen Y, Ye H,Li X, Lin Z, Wang Z, Huang W and Ding X: Age-related changes in prevalence and symptom characteristics in kidney deficiency syndrome with varied health status: A cross-sectional observational study. J Tradit Chin Med Sci 1: 20-27, 2014

15. Tang ZH, Chen HB, Li WH, Su LX, Chen W, Qiong Z and Jan SL: Comparative study of epidemiological investigation and expert-evaluation system of kidney-yang insufficiency syndrome with old-aging. Liaoning J Tradit Chin Med 38: 611-613, 2011.

16. Gong Y, Liu L, He X, Zhao H, Yang J, Li L, Lu A, Lin Y and Jiang M: The th $17 /$ treg immune balance in ulcerative colitis patients with two different chinese syndromes: Dampness-heat in large intestine and spleen and kidney yang deficiency syndrome. Evid Based Complement Alternat Med 2015: 264317, 2015.

17. Ding WJ, Yan SL, Zeng YZ, Li WH, Duan A, Zheng TE, Liu M, Tan CE, Teng $X$ and Wan J: Insufficient activity of MAPK pathway is a key monitor of kidney-yang deficiency syndrome. J Altern Complement Med 15: 653-660, 2009.

18. Yang J, Wang Y, Bao Y and Guo J: The total flavones from Semen cuscutae reverse the reduction of testosterone level and the expression of androgen receptor gene in kidney-yang deficient mice. J Ethnopharmacol 119: 166-171, 2008.

19. Julkunen I, Sareneva T, Pirhonen J, Ronni T, Melén K and Matikainen S: Molecular pathogenesis of influenza A virus infection and virus-induced regulation of cytokine gene expression. Cytokine Growth Factor Rev 12: 171-180, 2001.

20. Zaas AK, Chen M, Varkey J, Veldman T, Hero AO III, Lucas J, Huang Y, Turner R, Gilbert A, Lambkin-Williams R, et al: Gene expression signatures diagnose influenza and other symptomatic respiratory viral infections in humans. Cell Host Microbe 6 207-217, 2009

21. Wareing MD, Lyon AB, Lu B, Gerard C and Sarawar SR: Chemokine expression during the development and resolution of a pulmonary leukocyte response to influenza $\mathrm{A}$ virus infection in mice. J Leukoc Biol 76: 886-895, 2004

22. Tang N, Liu L, Qiu H, Shi W and Mao D: Analysis of gene expression and functional changes of adrenal gland in a rat model of kidney yang deficiency syndrome treated with Sini decoction. Exp Ther Med 16: 3107-3115, 2018.

23. Wang ZX, Shao YY, Ming L, Yi L and Ji R: Influence of bokhi on kidney-yang-deficiency syndrome in rats. J Camel Pract Res 24 281-290, 2017

24. Zhao S, Yuan L, Li Y, Liu L, Luo Z, Lv Q, Rong R and Yang Y: Secretory $\operatorname{IgA}$ in mucosa of pharynx and larynx plays an important role against influenza A virus infection in kidney yang deficiency syndrome model. Evid Based Complement Alternat Med 2020: 9316763, 2020.

25. Leong PK, Wong HS, Chen J and Ko KM: Yang/Qi invigoration: An herbal therapy for chronic fatigue syndrome with yang deficiency? Evid Based Complement Alternat Med 2015: 945901,2015.

26. Wang CM, Xu SY, Lai S, Geng D, Huang JM and Huo XY Curculigo orchioides (Xian Mao) modifies the activity and protein expression of CYP3A in normal and kidney-yang deficiency model rats. J Ethnopharmacol 144: 33-38, 2012.

27. Xin C, Xia Z, Jiang C, Lin M and Li G: Xiaokeping mixture inhibits diabetic nephropathy in streptozotocin-induced rats through blocking TGF- $31 / \mathrm{Smad} 7$ signaling. Drug Des Devel Ther 9: 6269-6274, 2015 .

28. Li B, Qing T, Zhu J, Wen Z, Yu Y, Fukumura R, Zheng Y, Gondo $Y$ and Shi L: A comprehensive mouse transcriptomic BodyMap across 17 tissues by RNA-seq. Sci Rep 7: 4200, 2017.

29. Reemers SS, van Haarlem DA, Groot Koerkamp MJ and Vervelde L: Differential gene-expression and host-response profiles against avian influenza virus within the chicken lung due to anatomy and airflow. J Gen Virol 90: 2134-2146, 2009.

30. Yin CC, Yang Y, Li J, Li RR, Rong R and Meng H: Establishment and evaluation of mice model with kidney yang deficiency infected by influenza virus. Chin J Exp Tradit Med Formulae 19 253-256, 2013.

31. Chen SH, LU GY, Fan J, Yan MQ, Ye H, Fang Z, Tang XH and Wu HF: Effects of different extracts from Hippocampus Japonicus on kidney-yang deficiency mice induced by extradiol. Chin Tradit Herbal Drugs 258-262, 2009.

32. Wang ZJ, Sun L, Peng W, Ma S, Zhu C, Fu F and Heinbockel T: Ginseng derivative ocotillol enhances neuronal activity through increased glutamate release: A possible mechanism underlying increased spontaneous locomotor activity of mice. Neuroscience 195: 1-8, 2011
33. Can A, Dao DT, Arad M, Terrillion CE, Piantadosi SC and Gould TD: The mouse forced swim test. J Vis Exp 29: e3638, 2011.

34. Chen SH, Lv GY, Fan J, Yan MQ, Shan LT, Fang Z, Li HH, Su J and $\mathrm{Li}$ W: Therapeutic effect of petroleum ether extract from Semen cuscutae against $\beta$-estradiol 3-benzoate induced kidney-yang deficiency in mice. Afr J Pharm Pharmacol 5: 700-705, 2011.

35. Edouard MJ, Miao L, Fan GW, Ojong BB, Zhen H, Zhang J, Gao XM and Zhu Y: Yang-tonifying traditional Chinese medicinal plants and their potential phytoandrogenic activity. Chin J Nat Med 12: 321-334, 2014.

36. Hellemans J, Mortier G, De Paepe A, Speleman F and Vandesompele J: qBase relative quantification framework and software for management and automated analysis of real-time quantitative PCR data. Genome Biol 8: R19, 2007.

37. Kugelberg E: Pattern recognition receptors: Curbing gut inflammation. Nat Rev Immunol 14: 583, 2014.

38. Akira S, Uematsu S and Takeuchi O: Pathogen recognition and innate immunity. Cell 124: 783-801, 2006.

39. Xiang Q, Li J, Qin P, He M, Yu X, Zhao K, Zhang X, Ma M, Chen $Q$, Chen X, et al: Identification and evaluation of reference genes for qRT-PCR studies in Lentinula edodes. PLoS One 13: e0190226, 2018.

40. Lacerda AL, Fonseca LN, Blawid R, Boiteux LS, Ribeiro SG and Brasileiro AC: Reference gene selection for qPCR analysis in tomato-bipartite begomovirus interaction and validation in additional tomato-virus pathosystems. PLoS One 10: e0136820, 2015.

41. Gong H, Sun L, Chen B, Han Y, Pang J, Wu W, Qi R and Zhang TM: Evaluation of candidate reference genes for RT-qPCR studies in three metabolism related tissues of mice after caloric restriction. Sci Rep 6: 38513, 2016.

42. Zeng J, Liu S, Zhao Y, Tan X, Aljohi HA, Liu W and Hu S: Identification and analysis of house-keeping and tissue-specific genes based on RNA-seq data sets across 15 mouse tissues. Gene 576: 560-570, 2016

43. Luduena RF: Multiple forms of tubulin: Different gene products and covalent modifications. Int Rev Cytol 178: 207-275, 1998.

44. Sullivan KF and Cleveland DW: Identification of conserved isotype-defining variable region sequences for four vertebrate beta tubulin polypeptide classes. Proc Natl Acad Sci USA 83: 4327-4331, 1986

45. Gunning PW, Ghoshdastider U, Whitaker S, Popp D and Robinson RC: The evolution of compositionally and functionally distinct actin filaments. J Cell Sci 128: 2009-2019, 2015.

46. Güssow D, Rein R, Ginjaar I, Hochstenbach F, Seemann G, Kottman A and Ploegh HL: The human beta 2-microglobulin gene. Primary structure and definition of the transcriptional unit. J Immunol 139: 3132-3138, 1987

47. Shipley JM, Grubb JH and Sly WS: The role of glycosylation and phosphorylation in the expression of active human beta-glucuronidase. J Biol Chem 268: 12193-12198, 1993.

48. Sirover MA: Role of the glycolytic protein, glyceraldehyde-3-phosphate dehydrogenase, in normal cell function and in cell pathology. J Cell Biochem 66: 133-140, 1997.

49. Suzuki T, Higgins PJ and Crawford DR: Control selection for RNA quantitation. Biotechniques 29: 332-337, 2000

50. Kawada J, Kimura H, Kamachi Y, Nishikawa K, Taniguchi M, Nagaoka K, Kurahashi H, Kojima S and Morishima T: Analysis of gene-expression profiles by oligonucleotide microarray in children with influenza. J Gen Virol 87: 1677-1683, 2006.

51. Kuchipudi SV, Tellabati M, Nelli RK, White GA, Perez BB, Sebastian S, Slomka MJ, Brookes SM, Brown IH, Dunham SP and Chang KC: $18 \mathrm{~S}$ rRNA is a reliable normalisation gene for real time PCR based on influenza virus infected cells. Virol J 9: 230,2012

This work is licensed under a Creative Commons Attribution-NonCommercial-NoDerivatives 4.0 International (CC BY-NC-ND 4.0) License. 